\title{
Comparison of extractive chemical signatures among branch, knot and bark wood fractions from forestry and agroforestry walnut trees (Juglans regia $\times$ J. nigra) by NIR spectroscopy and LC-MS analyses
}

\author{
Lucie Heim ${ }^{(1-2-3)}$, \\ Roxane Dodeler ${ }^{(1-2-3)}$, \\ Loiic Brancheriau ${ }^{(1-2)}$, \\ Remy Marchal ${ }^{(3)}$, \\ Nabila Boutahar ${ }^{(1-2)}$, \\ Sylvain Lotte ${ }^{(1-2)}$, \\ Stéphane Dumarçay ${ }^{(4)}$, \\ Philippe Gérardin ${ }^{(4)}$, \\ Kevin Candelier ${ }^{(1-2)}$
}

\begin{abstract}
Walnut agroforestry systems require regular tree pruning, generating a large volume of biomass residues which are mainly valorized as wood-energy, Ramial Chipped Wood (RCW) or animal litter. However, walnut is recognized as a rich source of different chemical compounds, which could be recovered as valuable chemicals. This study aims to improve the knowledge on the composition of the water and ethanol extractive contents of wood, knot and bark fractions from walnut branches, harvested in agroforestry (AF) and traditional forestry control (FC) systems. LC-MS analyses were carried out to identify the chemical composition of extracts. Additionally, all samples were analyzed by near-infrared (NIR) spectroscopy with the aim of developing a fast tool to distinguish walnut branches, knots and bark wood fractions from trees grown under agroforestry and plantation management. Extractive contents and chemical composition of AF and FC wood samples were slightly different among branch, knot and bark. Despite these small chemical differences, PLS-DA models based on NIRS measurements can distinguishing among wood samples from walnut trees grown under different silvicultural regimes. In addition, in the both forestry systems, branch and knot extractive contents were significantly lower than those of bark specimens. Principal Component Analyses (PCA) based on NIRspectrometry of raw samples revealed that the chemical composition of branch and knot woods are similar to each other and are very different compared to those of bark samples. This study provides new knowledge on branch woods from agroforestry systems, which are still very under-studied at present.
\end{abstract}

\section{Keywords: Agroforestry, Bark, Branches, Extractives, Knot, Walnut}

\section{Introduction}

Agroforestry is based on the combination of trees and crops cultivation. Compared to traditional arable and forestry systems, this practice makes available resources that can be more effectively exploited, while respecting the environment with an obvious landscape benefit (Dupraz \& Liagre 2019). Agroforestry allows for the diversification of farm activities and involves a better use of environmental resources. In addition, agroforestry farms can become over time less dependent on crop subsidies, and less susceptible to crop price variations, as timber generates a significant part of their income (Dupraz et al. 2005). In addition to the potential valorization of standing wood, agroforestry systems require regular tree pruning, thus generating a large volume of biomass residues over the entire period of exploitation. These agroforestry wastes are today mainly valorized as wood-energy, Ramial Chipped Wood (RCW) or animal litter (Malignier \& Balaguer 2017).

Walnut trees have high marketing demand in Europe, due to their high quality timber. The walnut tree is perfectly suitable to agroforestry system, because of the relatively low competition for light with crops due to its characteristics such as a more open crown, late leafing and early leaf fall. In addition, walnut tree leaves form a good litter which speeds up nutrient cycling (Pardon et al. 2020). Walnut tree is also recognized as a rich source of many valuable chemicals from the kernel, fresh green fruit, husk, shell, skin, bark, leaves, and root, which are largely used by food, cosmetic and pharmaceutical industries. In this respect, all parts of walnut tree are an excellent source of highly active compounds with antioxidant, antimicrobial and insecticidal potential (Salejda et al. 2016).

In general, wood from branches and bark has been poorly investigated as compared to trunk wood. This lack of information prevents branch wood from entering many productive paths. Recent studies highlighted that the chemical signature in extractives (composition and rate) is different among tree organs (Jahanban-Esfahlan et al. 2019). For several woody species, stem knots and bark have been particularly studied, and in most cases, the knots resulted richer in extractives than the trunk and branches in both hardwoods and softwoods (Košíková 2009, Kebbi-Benkeder et al. 2015). The branches also seem to be 


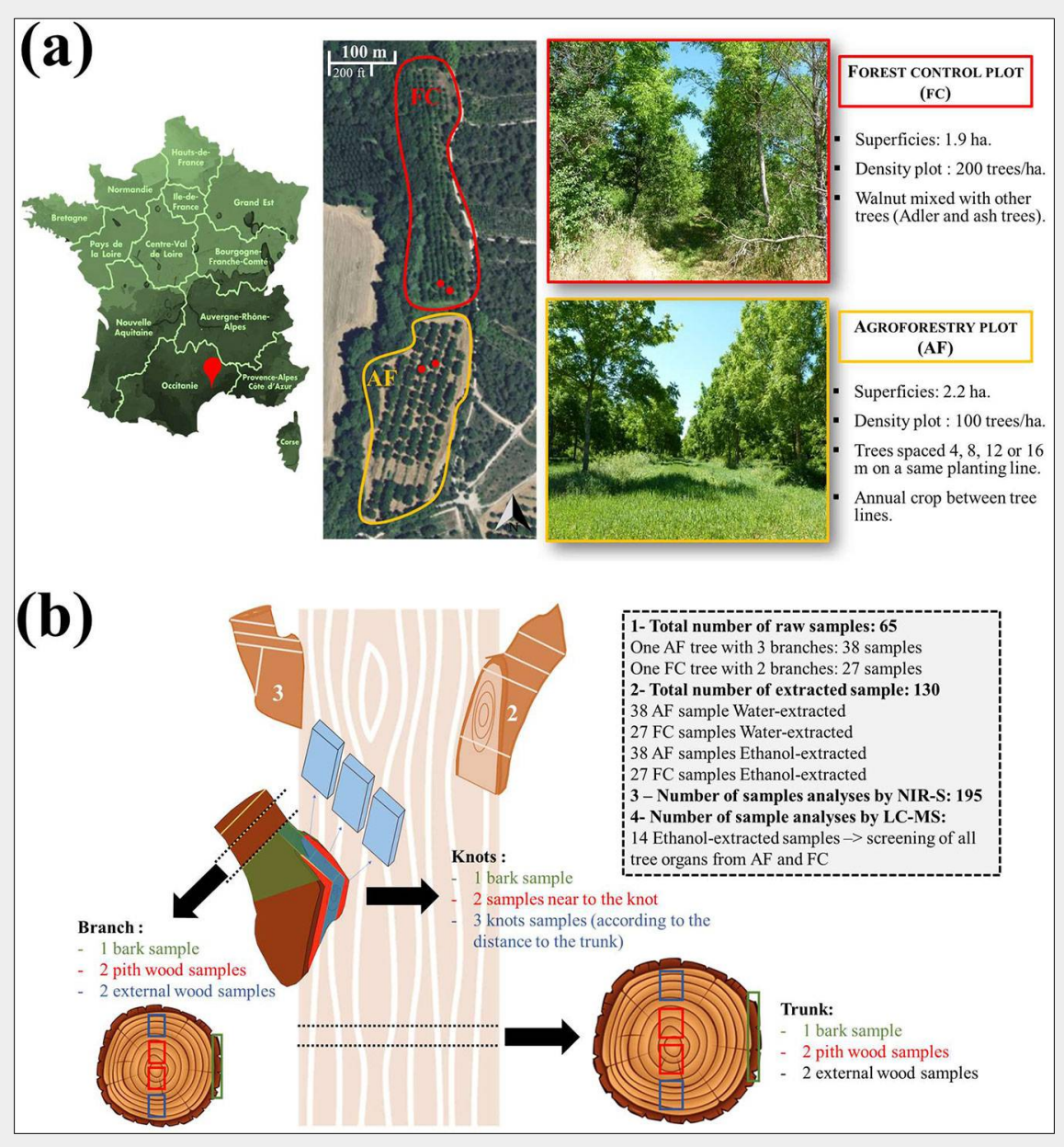

Fig. 1 - (a) Walnut trees selection in the agroforestry (AF) and forestry control (FC) plots at the Restinclières farm (southern France); (b) description of the sampling schema, processing and selection of the wood samples.

richer in extractives than the trunk clear wood, though they are poorer than the knots (Xu et al. 2007, Morikawa et al. 2014). Terrasse et al. (2021) showed that the content in extractives of walnut tree was quite similar in branches and trunks, both in terms of absolute value and distribution. Indeed, the extractive content decreases along the branch with the distance to the trunk and slightly increases radially with the distance to the pith.

The content in extractives can vary according to many factors, including the environment, the genetic make-up, tree age and the season (Toshiaki 2001, Haupt et al. 2003). Recent studies demonstrated that changes in environmental conditions during growth can significantly alter the heartwood extractive content in some species. If such variation in heartwood extractives affect wood properties, then silvicultural treatments and changes in forest management regime may affect the value of the derived wood products (Taylor et al. 2006). The NIR (Near-InfraRed) spectroscopy has been efficiently used for the assessment of chemical properties of walnut wood (Terrasse et al. 2021). Schimleck et al. (2003) showed that it is possible to accurately calibrate NIR models for a wide range of species that represent different ties. NIR absorbance spectra are related to the chemical composition of the tested wood sample (Leblon et al. 2013).

This study aims to improve the knowledge about the hydrophilic extractive contents of walnut trees and their chemical compositions (by LC-MS analyses), to investigate the potential of branch wood from agroforestry practices as base material to develop green chemistry and/or to manufacture biomaterials. NIR-spectroscopy was applied with the aim of developing a fast tool to assess the branch wood properties from agroforestry (AF) and forestry (FC) walnut branches, knots and wood fractions.

\section{Material and methods}

\section{Experimental site}

The experiment was carried out at the Restinclières farm in southern France $\left(43^{\circ}\right.$ $42^{\prime} 59^{\prime \prime} \mathrm{N}, 03^{\circ} 51^{\prime} 33^{\prime \prime} \mathrm{E}$; elevation $61 \mathrm{~m}$ a.s.l.). Two plots with 25 -years-old walnut trees were established: an agroforestry plot (AF) with 140 trees, and a forestry control plot (FC) with 235 trees. The initial planting density was identical in both plots. taxa, wood chemistry and physical proper-
A thinning in 2004 reduced the density at the AF plot to 100 trees ha ${ }^{-1}$, with trees spaced $4,8,12$ or $16 \mathrm{~m}$ along a same planting line. Between each line, winter cereal crops were cultivated. In the FC plot, the walnut trees were mixed with alders (Alnus cordata [Loisel.] Duby) and ash (Fraxinus excelsior L.), with an overall density of about 200 trees ha $^{-1}$. In both plots, tree rows were oriented in north-south direction (Fig. 1a).

\section{Tree selection}

Two hybrid walnut (Juglans nigra $\times$ J. regia) trees from the AF plot and two from the FC plot were chosen (Fig. 1a) and harvested in February 2020 in order to limit the seasonal impact on chemical composition of wood (e.g., starch in sapwood). The sample trees were selected in the distal part of their respective plots to avoid the effect of soil and water exposure variations.

\section{Samples repartitions}

The sampling details are summarized in Fig. 1b. A similar sampling schema was applied to each trunk and branch of the selected trees at both AF and FC plots. The total number of samples, including branch and trunk wood, knot wood and bark, was 195. All of these samples were analyses by NIR-Spectroscopy, while only a representative subset of 14 ethanol-extracted samples were characterized by LC-MS analyses.

\section{Samples preparation and conditioning}

Each of the 65 raw samples (Fig. 1b) from $\mathrm{AF}$ and $\mathrm{CF}$ plots was firstly oven-dried at $103 \pm 2{ }^{\circ} \mathrm{C}$ for 24 hours, and then ground and passed through different sieves to obtain particles ranging $0.2-0.5 \mathrm{~mm}$. Twenty grams of each sample were then stabilized at a moisture content (MC) of $12 \%$ (stabilization in an humid air at $20 \pm 2{ }^{\circ} \mathrm{C}$ and $65 \pm$ $5 \% \mathrm{RH}$ ) before NIR-S analyses and extraction processes.

\section{Extraction processes}

All experimental procedures for the determination of the extractive content were adapted with minor modifications from Rowell et al. (2005).

Each sample was oven-dried at $103{ }^{\circ} \mathrm{C}$ to determine its initial anhydrous mass $\left(m_{0}\right)$; then $15 \mathrm{~g}$ (in dry basis) was extracted in a Soxhlet with ethanol (Sigma Aldrich, 32201M) during 8 hours. After this first extraction, the sample was oven-dried again until mass stabilization $\left(m_{1}\right)$, before being submitted to a second extraction with hot distilled water for 7 hours, and then dried once again at $103^{\circ} \mathrm{C}$ to obtain the final anhydrous mass $\left(\mathrm{m}_{2}\right)$.

The extractive contents were determined according to the following equations (eqn. 1, eqn. 2 ):

$$
E_{e t h}(\% D W)=\frac{m_{0}-m_{1}}{m_{0}} \cdot 100
$$




$$
E_{\text {water }}(\% D W)=\frac{m_{1}-m_{2}}{m_{0}} \cdot 100
$$

where $E_{\text {eth }}$ and $E_{\text {water }}$ are the sample extractive contents using ethanol and water, respectively, expressed as percentage of dry weight (DW), $m_{0}$ is the theoretical anhydrous mass of the test specimen before extraction, $m_{1}$ and $m_{2}$ are the anhydrous masses after ethanol and water extractions, respectively, expressed in grams.

A total of 130 powder samples were characterized for their hydrophilic (water extraction) and lipophilic (toluene: ethanol extraction) extraction rate (Fig. 1b). The overall standard error of the extractive content estimates was $2.70 \pm 0.04 \%$, which was considered acceptable.

\section{NIR-spectrometry}

Near infrared spectra were obtained on raw and extracted powder samples previously stabilized at a moisture content (MC) of $12 \%$. A MicroNIR OnSite-W ${ }^{\circledast}$ (VIAVI Solutions Inc., Scottsdale, AZ, USA) spectrophotometer was used in reflectance mode. Measures were taken at wavelengths between 908 and $1676 \mathrm{~nm}$ in 6.2 $\mathrm{nm}$ increments; thus, the spectra were composed by the reflectance values at 125 different wavelengths.

\section{LC-MS analyses}

The chemical compositions of branch wood, knots and bark extracts in ethanol were analyzed by liquid chromatography followed by mass spectroscopy (LC-MS) experiments. Preliminary experiments revealed that water extracts were not efficiently analyzed by LC-MS.

Ten milligrams of freeze-dried extract and $1 \mathrm{ml}$ of ethanol were added in a $1.5 \mathrm{ml}$ clear glass autosampler vial (VWR, Radnor, PA, USA). Samples were solubilized in an ultrasonic bath (Elmasonic S15 ${ }^{\oplus}$, VWR, Fontenay-sous-Bois, France) for $2 \mathrm{~min}$. Liquid chromatography was carried out using a Shimadzu LC-20A ${ }^{\circledast}$ ultra-HPLC system (Shimadzu, Kyoto, Japan) equipped with an autosampler and interfaced with an SPD-20A photodiode-array (PDA) UV detector recording spectra between 190 and $800 \mathrm{~nm}$. Separation was achieved on a $\operatorname{LunaC} 18^{\circledR}$ analytical column $(150 \times 3 \mathrm{~mm}$ - Phenomenex, Torrance, CA, USA). The injection volume was $5 \mu \mathrm{l}$, the flow rate was $0.4 \mathrm{ml}$ $\mathrm{min}^{-1}$, and the gradient profile was the following: starting from $5 \%(\mathrm{v} / \mathrm{v})$ acetonitrile $\left(\geq 99.9 \%\right.$, LC-MS Chromasolv ${ }^{\mathrm{TM}}$ ) in water (LCMS Chromasolv $\left.{ }^{\mathrm{TM}}\right)$ both containing $0.1 \%(\mathrm{v} /$ v) formic acid, $30 \%$ acetonitrile ( $/ \mathrm{v}$ ) was reached at $4.0 \mathrm{~min}$ then $90 \%$ acetonitrile at 7.0 min was maintained until 9.5 min. Mass spectrometry was done with a Shimadzu LC-MS $8030^{\circledast}$ triple quadrupole mass spectrometer. Positive and negative ion electrospray mass spectrometric analyses were carried out at a unit resolution between 100 and $2000 \mathrm{~m} / \mathrm{z}$ at a scan speed of 15,000 amu $\mathrm{s}^{-1}$. The heat block and desolvation line temperatures were 400 and $250^{\circ} \mathrm{C}$, respec- tively. Nitrogen was used as drying (15 I $\left.\mathrm{min}^{-1}\right)$ and nebulizing $\left(3 \mid \mathrm{min}^{-1}\right)$ gas. The ion spray voltage was $\pm 4500 \mathrm{~V}$. Data were acquired and analyzed with the Lab Solutions software (v. 5.92SP4, Shimadzu). Identification of compounds was done by comparing peak retention times, UV, MS and $\mathrm{MS}^{2}$ spectra to the literature and to standard solutions of (+)- catechin hydrate (98\% HPLC, Sigma-Aldrich) and (-)- epicatechin (90\%, Sigma Aldrich).

\section{Statistical analyses}

Statistical analyses were performed using the software RStudio Desktop ${ }^{\circledR}$ v. 1.2 (RStudio Inc., Boston, MA, USA). To test for differences in the extractive contents among branches, knots and bark wood from AF and FC walnut trees, the Kruskall-Wallis test was applied to each potentially explicative factor and response variable. When an effect of the factor on a studied variable was detected, Wilcoxon test was used to investigate the nature of this effect and the significance of the differences between the groups of modalities in the descriptive variables.

NIRS spectra were first transformed using a Standard Normal Variate (SNV) correction (Naes et al. 2004) to reduce the effect of irregularities of surface and the intra spectrum variability (correction of the light dispersion). The second derivative was then computed using the Savitzky Golay algorithm with a smoothing range of 11 data points and a third degree polynomial (Savitzky \& Golay 1964). The use of this derivative allows to separate overlapping peaks and correct the baseline deviation of spectra. Mathematical corrections were applied using the package "prospectr" $v$.
0.1.3 in the R environment. Principal component analysis (PCA) was applied through the package "FactoMineR" (v. 1.34) on the transformed NIRS spectra to detect possible differences in chemical composition between samples and the presence of groups within the tested samples (raw samples of $\mathrm{AF}$ and (F branch, knots and bark). NIRS models were developed using the Partial Least Squares - Discriminant Analysis regression method (PLS-DA) using the package "mdatools" v. 0.11.5, in order to discriminate the samples as AF or FC, according to the chemical composition of branch, knots and bark samples.

\section{Results and discussions}

Variability in extractive contents within $A F$ and $F C$ tree

As shown in Fig. 2, the water extractive contents were higher than those extracted using ethanol for the branch, knot and bark fractions of both AF and FC samples. Similar results were found by Kebbi-Benkeder et al. (2015) who analyzed the water and toluene:ethanol extracts from knotwood and heartwood from various hardwood and softwood species. For most species, the authors reported that water-extractive contents of knot and heartwood fractions were higher than those obtained by extraction in toluene:ethanol. Hardwood species contain more hydrophilic than lipophilic extractives (Vek et al. 2014).

According to the literature, ethanol and water extractive contents of the bark were significantly different from those of branch and knot wood fractions. Many previous studies reported that bark contained higher level of extractives than knotwood,
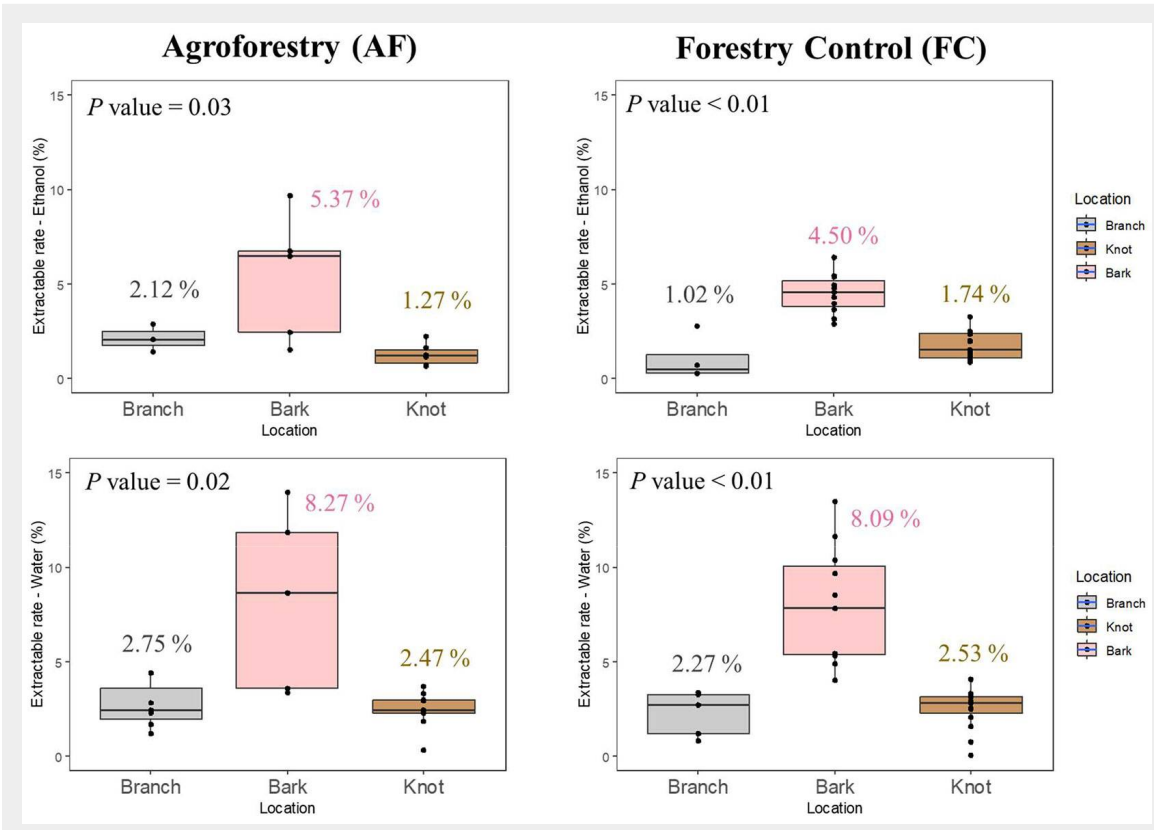

Fig. 2 - Mean extractive content from branch, bark and knot wood of walnut trees grown in agroforestry (AF) and forestry control (FC) systems. P value $<0.05$ indicate significant differences in extractive contents between branch (grey boxes), bark (pink boxes) and knot (brown boxes) wood fractions after Kruskal-Wallis test. 


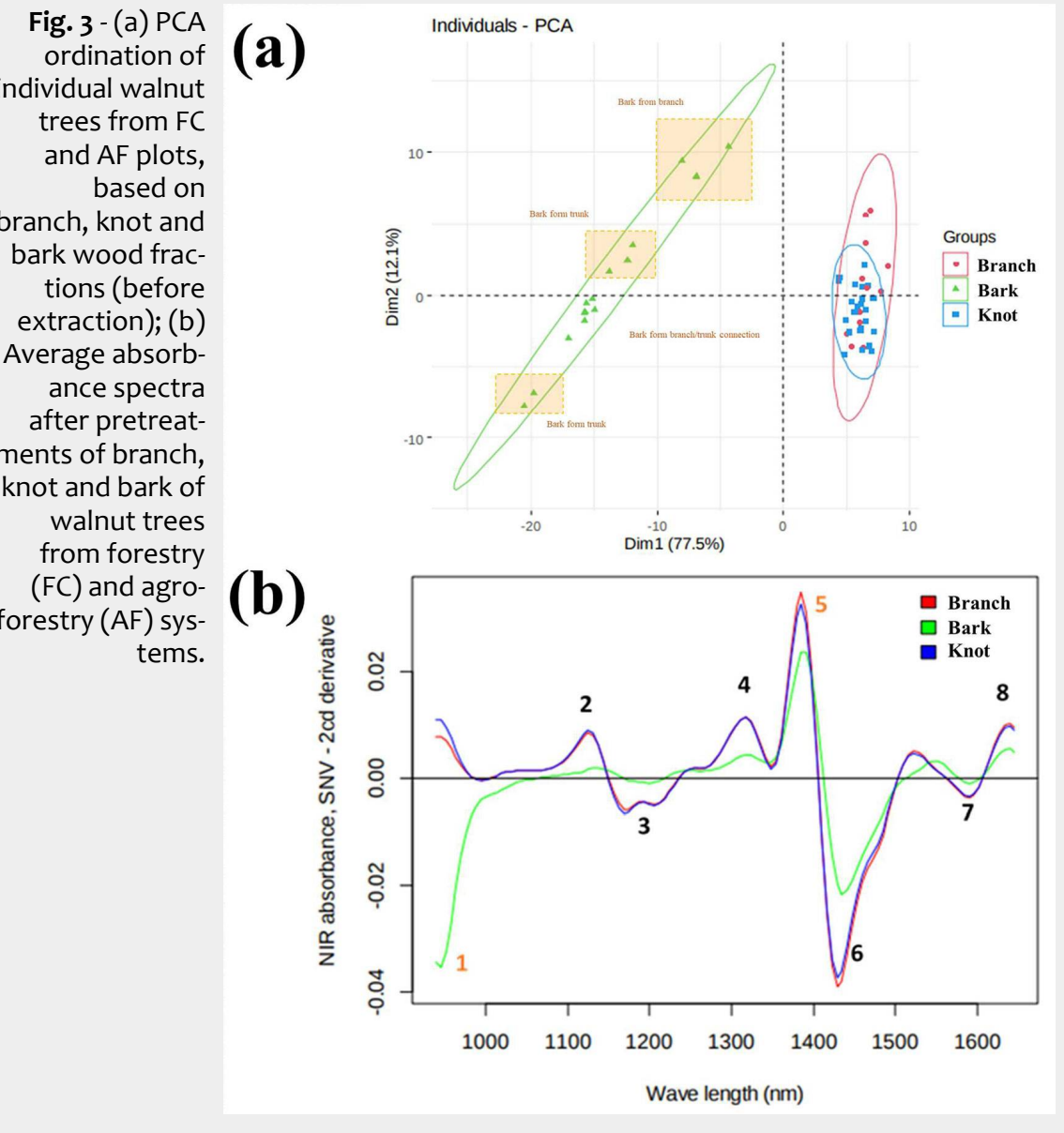

sapwood and heartwood (Rowe \& Conner study. The similar values in extractive con1979). However, knotwood has been tents between knot and branch wood samshown to contain more extractives than ples could be attributed to the young age sapwood and heartwood (Kebbi-Benkeder (25 years) of the AF and FC walnut trees, et al. 2015, 2016). These findings are in con- which is reflected by the scarce or null trast with the results obtained in this presence of duramen in the trunk and branches of the studied trees. According to the literature, the proportion of extracts in the wood can greatly increase during the duramenization process, as well as for the presence of tension or compression wood and past damage (Vek et al. 2014).

PCA confirmed the abovementioned results (Fig. 3a), revealing that the chemical composition of branch (in red) and knot (in blue) wood samples is similar to each other and very different compared to that of bark (in green) samples.

Fig. 3b shows the average NIRS spectra of branch, knot and bark of walnut trees from FC and AF samples. Tab. 1 indicates the NIRS absorption bands normally associated with the main chemical components contained in the wood specimens. It is fairly clear that the differences in chemical composition of the tree organs depend on differences in the content of hemicelluloses (peak 4) and celluloses (peaks 6 and 7 ), but also on the amount of lignin (peaks 2,3 and 8 ) and the proportion of extractives (peaks 1 and 5).

\section{Differences in the extractive content between AF and FC trees}

Fig. 4 displays the mean ethanol and water extractive contents of branch, knot and bark samples from AF and FC walnut trees. The extractive content of branch and bark of AF walnut seems slightly higher than that of FC trees, whereas the opposite was observed for knot samples. However, no significant difference in these extractive contents were found between AF and FC walnut tree organs after Wilcoxon test.

It could be hypothesized that the above differences could be attributed to the thinning operations carried out at the AF plot, which could have promoted an increment

Tab. 1 - NIRS absorption bands normally associated with the main wood components (cellulose, hemicelluloses, lignin, extractives and water) contained in wood specimens. Index numbers refer to the specific bands in Fig. 5 .

\begin{tabular}{|c|c|c|c|c|c|}
\hline Index & $\begin{array}{l}\text { Wavenumber } \\
\text { Bands }(\mathrm{nm})\end{array}$ & Bond Vibration & Structure & Remarks & References \\
\hline 1 & $900-980$ & - & Lignin / Extractives & $\begin{array}{l}\text { The major vibrations include the } \\
\text { yellow-brown color of the wood that } \\
\text { are primarily due to the presence of } \\
\text { lignin and extractives }\end{array}$ & $\begin{array}{l}\text { Kelley et al. (2004) Yi } \\
\text { et al. (2017) }\end{array}$ \\
\hline 2 & $1100-1150$ & $\mathrm{HC}=\mathrm{CH}$ & Lignin & - & $\begin{array}{l}\text { Workman \& Weyer } \\
\text { (2007) }\end{array}$ \\
\hline 3 & $1150-1200$ & $\begin{array}{l}\text { First and second overtones of } \\
\text { the lignin aromatic and } \\
\text { aliphatic carbon/hydrogen } \\
\text { vibrations }\end{array}$ & Lignin & - & Kelley et al. (2004) \\
\hline 4 & $1290-1330$ & $\begin{array}{l}\text { First overtone } \mathrm{C}-\mathrm{H} \text { stretching } \\
+\mathrm{C}-\mathrm{H} \text { deformation }\end{array}$ & Hemicelluloses / all & $\begin{array}{l}\text { Tentative assignment to } \mathrm{CH} 3 \text { groups } \\
\text { in acetyl ester groups in } \\
\text { hemicelluloses and lignin and all } \\
\text { wood components after acetylation }\end{array}$ & $\begin{array}{l}\text { Schwanninger et al. } \\
\text { (2011) }\end{array}$ \\
\hline 5 & $1350-1400$ & First overtone $\mathrm{O}-\mathrm{H}$ stretching & Lignin / Extractives & Vibration of phenolic hydroxyl groups & Donald \& Burns (2007) \\
\hline 6 & $1400-1500$ & First overtone $\mathrm{O}-\mathrm{H}$ stretching & Cellulose & Amorphous regions in cellulose & Fujimoto et al. (2007a) \\
\hline 7 & $1570-1600$ & First overtone $\mathrm{O}-\mathrm{H}$ stretching & Cellulose & Crystalline region of cellulose & $\begin{array}{l}\text { Tsuchikawa \& Siesler } \\
\text { (2003) }\end{array}$ \\
\hline 8 & $1610-1650$ & $\mathrm{C}-\mathrm{H}$ stretching & Lignin & - & $\begin{array}{l}\text { Fujimoto et al. } \\
\text { (2007b) }\end{array}$ \\
\hline
\end{tabular}




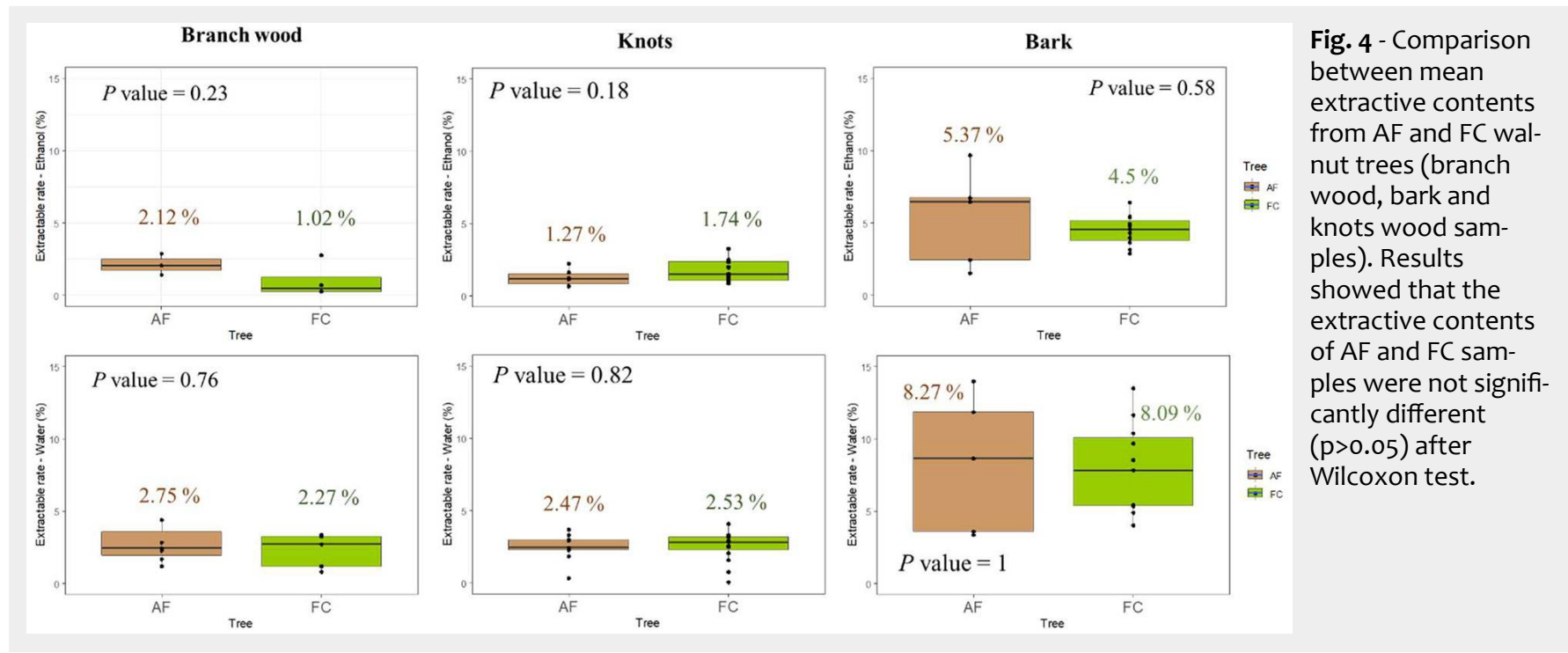

in the heartwood proportion of the remaining trees (Hapla et al. 2000). Indeed, the lower tree density at the AF plot compared to that at the FC plot could have favoured the production of wood with higher lignin, hemicelluloses and extractive contents in the AF walnut trees (Moulin et al. 2015). Harmaen et al. (2014) found that hot water-extractive contents of rubberwood, whatever the position of the wood sample along the tree stem, decreased when the stand density increases.

Partial least squares discriminant analysis (PLS-DA with cross validation "leave-oneout") was carried out with the aim of developing models for the fast classification of branch, knot and bark samples according to the forestry system. As shown in Fig. 5, the PLS-DA models allowed for a large percentage of correct classifications for FC wood, knot and bark specimens. Only one FC bark specimen was misclassified as AF bark sample, indicating that this native FC sample has characteristics similar, to some extent, to those of the AF trees. In contrast, three AF branch-knot and two AF bark specimens were confounded and classified as FC samples by the cross-validated models. The low robustness of the model concerning bark specimens seems mainly due to the small number of AF samples used in this analysis.

In summary, the findings obtained from PLS-DAs showed that chemical differences do exist between AF and FC samples, and these small differences in wood composition are sufficient to distinguish knots and bark wood specimens from trees grown in different forestry systems.

Previous studies based on NIR-spectrocopy analyses found similar results in the classification of wood samples from different species, locality and types of plantations. Ramalho et al. (2018) highlighted that PLS-DA models based on treated NIR signatures are robust for classifying Eucalyptus wood specimens from natural and planted forests. Pace et al. (2019) correctly classified 12 native wood species from a ho- mogeneous plantation based on the respective NIR spectra, showing the good performance of PLS-DA models in classifying independent native wood samples.

Chemical composition of extractives from $A F$ and $F C$ trees

According to LC-MS analysis, the major components in ethanol extracts of branch, knot and bark specimens from AF and FC walnut were identified and qualified (Tab. 2), but not quantified. In agreement with Toshiaki (2001), the main components of $\mathrm{AF}$ and $\mathrm{FC}$ branch wood extracts are lignans, followed by sterols and flavonoids, mostly represented by secoisolariciresinol, campestestrol and quercetin, respectively. $\mathrm{AF}$ and $\mathrm{FC}$ knot specimens are mainly composed by secoisolariciresinol and balanophonin (lignans) following by oleuropeinaglycone and gallic acid (phenolic acids), mono-O-galloyl-glucose (phenolic acids glycoconjugate) and quercetin (flavonoids). Sakuranetin, quercetin and isoquercitrin are the main flavonoid components pres-

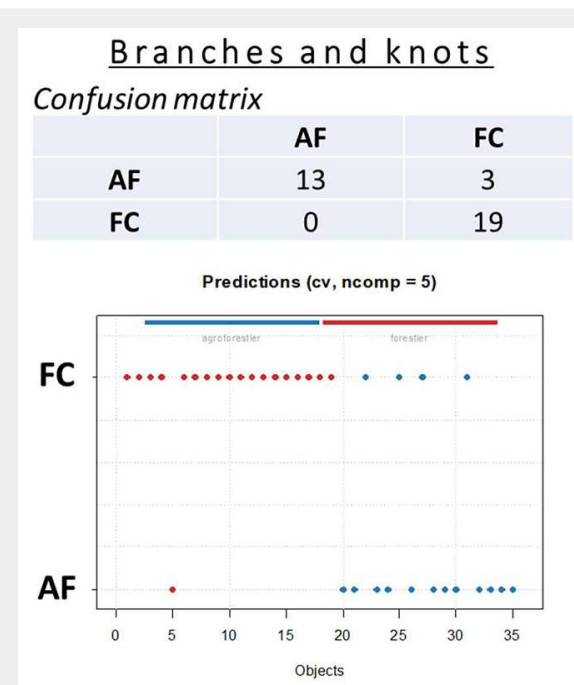

ent in the bark samples, following by syringic acid (phenolic acids) and campesterol (sterols).

The presence of all these components is in agreement with the specific literature. Walnut bark extract contains several therapeutically active constituents, especially flavonoids as quercetin (Zakavi et al. 2013), polyphenols (mostly gallic acid) and sterols (Bhatia et al. 2006, Nirmla Devi et al. 2011). Flavonoids occur in bark, heartwood, flower, fruit, seed and root of many plants (Toshiaki 2001). Lignans and neolignans are phenylpropanoids found in many woody plants including softwoods and hardwoods (Toshiaki 2001). Tannins are water-soluble phenolic compounds. Polyphenols are widely distributed in wood, bark, and leaves of many plants. They are classified into hydrolysable and condensed tannins (Toshiaki 2001). Hydrolysable tannins are esters of an aliphatic polyol and phenolic acids and can be hydrolyzed into gallic or ellagic acid (Toshiaki 2001). The condensed tannins and related polyflavonoids are ex-

\begin{tabular}{c|c|c}
\multicolumn{3}{c}{ Barks } \\
Confusion matrix & \\
\hline & AF & FC \\
\hline AF & 3 & 2 \\
\hline FC & 1 & 10
\end{tabular}

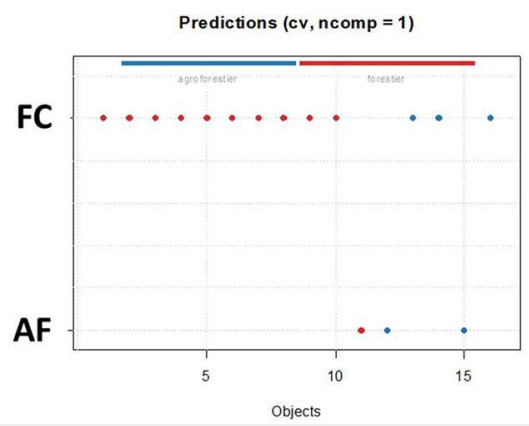

Fig. 5 - Results of the discriminant analyses (PLS-DA) based on NIRS data of branch, bark and knot wood samples from AF and FC plots. 
Tab. 2 - List of the chemical compounds identified by LC-MS analysis in the ethanol extracts from AF and FC branch, knot and bark fractions. (++): present in high quantity; (+): present in medium quantity; (-): present in low quantity; (--): present in trace; $(\varnothing)$ : absent.

\begin{tabular}{|c|c|c|c|c|c|c|}
\hline \multirow{2}{*}{$\begin{array}{l}\text { Chemical } \\
\text { compounds }\end{array}$} & \multirow{2}{*}{$\begin{array}{c}\text { Molar } \\
\text { Weight } \\
\left(\mathrm{g} \mathrm{mol}^{-1}\right)\end{array}$} & \multicolumn{4}{|c|}{$\begin{array}{c}\text { Presence in } \\
\text { ethanol-extracted samples }\end{array}$} & \multirow{2}{*}{$\begin{array}{l}\text { Class of } \\
\text { Compounds }\end{array}$} \\
\hline & & Modality & Branch & Knot & Bark & \\
\hline \multirow{2}{*}{ Malic acid } & \multirow{2}{*}{134} & $\mathrm{AF}$ & - & -- & - & \multirow{2}{*}{ Carboxylic acid } \\
\hline & & FC & - & $\varnothing$ & - & \\
\hline \multirow{2}{*}{ Gallic acid } & \multirow{2}{*}{170} & $\mathrm{AF}$ & $\varnothing$ & + & - & \multirow{2}{*}{ Phenolic acids } \\
\hline & & FC & $\varnothing$ & + & - & \\
\hline \multirow{2}{*}{ Syringic acid } & \multirow{2}{*}{198} & $\mathrm{AF}$ & $\varnothing$ & $\varnothing$ & ++ & \multirow{2}{*}{ Phenolic acids } \\
\hline & & FC & $\varnothing$ & $\varnothing$ & ++ & \\
\hline \multirow{2}{*}{ Sakuranetin } & \multirow{2}{*}{286} & $\mathrm{AF}$ & $\varnothing$ & $\varnothing$ & ++ & \multirow{2}{*}{ Flavonoids } \\
\hline & & FC & $\varnothing$ & $\varnothing$ & ++ & \\
\hline \multirow{2}{*}{ Quercetin } & \multirow{2}{*}{302} & $\mathrm{AF}$ & + & + & ++ & \multirow{2}{*}{ Flavonoids } \\
\hline & & FC & + & + & + & \\
\hline \multirow{2}{*}{ Rhamnetin } & \multirow{2}{*}{316} & $\mathrm{AF}$ & - & + & $\varnothing$ & \multirow{2}{*}{ Flavonoids } \\
\hline & & FC & - & $\varnothing$ & ++ & \\
\hline \multirow{2}{*}{$\begin{array}{l}\text { 3.7- diméthyl- } \\
\text { quercetin }\end{array}$} & \multirow{2}{*}{330} & $\mathrm{AF}$ & $-\cdot$ & - & + & \multirow{2}{*}{ Flavonoids } \\
\hline & & FC & - & + & $\varnothing$ & \\
\hline \multirow{2}{*}{$\begin{array}{l}\text { Mono-0-galloyl- } \\
\text { glucose }\end{array}$} & \multirow{2}{*}{332} & $\mathrm{AF}$ & - & + & - & \multirow{2}{*}{$\begin{array}{l}\text { Phenolic acids } \\
\text { glycoconjugate }\end{array}$} \\
\hline & & FC & - & + & - & \\
\hline \multirow{2}{*}{ Balanophonin } & \multirow{2}{*}{356} & $\mathrm{AF}$ & $\varnothing$ & + & $\varnothing$ & \multirow{2}{*}{ Lignans } \\
\hline & & FC & $\varnothing$ & + & $\varnothing$ & \\
\hline Secoisolaricires- & 362 & $\mathrm{AF}$ & ++ & ++ & $\varnothing$ & I ionans \\
\hline inol & 362 & FC & ++ & ++ & $\varnothing$ & Lignans \\
\hline Oleuropein- & 278 & $\mathrm{AF}$ & $\varnothing$ & ++ & $\varnothing$ & Dhonolir arids \\
\hline aglycone & $3 / 8$ & FC & $\varnothing$ & ++ & $\varnothing$ & Pnenotic acias \\
\hline Quercitrin & 448 & $\mathrm{AF}$ & $\varnothing$ & $\varnothing$ & ++ & Flayonoids \\
\hline & & FC & $\varnothing$ & $\varnothing$ & ++ & \\
\hline & & $\mathrm{AF}$ & $\varnothing$ & $\varnothing$ & + & Flavonoids \\
\hline Isoquercitrin & 464 & FC & $\varnothing$ & $\varnothing$ & + & Flavonoids \\
\hline Campoctarol & 172 & $\mathrm{AF}$ & + & $\varnothing$ & + & Sterole \\
\hline Campesterol & $4 / 2$ & FC & + & $\varnothing$ & ++ & Sterols \\
\hline
\end{tabular}

tremely common in extracts, especially from bark (Rowe \& Conner 1979). Campesterol is one of the most significant and abundant sterol in bark (Halmemies et al. 2021). In addition, malic acid was the most abundant organic acid identified (Vek et al. 2014) and it is predominant in knotwoods. Schell (1997) also identified this acid as the principal organic acid in the xylem sap of beech roots.

Our results showed that the chemical compositions of branch and knot wood was slightly different between $\mathrm{AF}$ and $\mathrm{FC}$ samples (Tab. 2), whereas the difference in chemical composition between AF and FC bark specimens was more marked in terms of flavonoid compounds.

The dispersion of bark samples observed in the PCA (Fig. 3a) can be explained by the variation in chemical composition according to the bark position in the tree (branch, branch-trunk junction or trunk). The LC-MS analyses confirmed these results. The chemical composition of bark extractives in ethanol from branch, branch-trunk and trunk position, of mixed $\mathrm{AF}$ and $\mathrm{FC}$ walnut tree samples is shown in Fig. S1 (Supplementary material).

\section{Conclusion}

This study provides new knowledge on the chemical characteristics of branch wood from agroforestry systems, which is still poorly studied. The results obtained highlight the evolution and variability of the chemical characteristics of branch, knot and bark wood fractions from agroforestry hardwoods compared to the same species grown in plantations.

Extractives contents of AF and CF specimens are not significantly different for branch, knot and bark. However, PLS-DA models developed based on NIR-S measures showed that chemical differences exist between AF and FC samples, and these differences in composition (though small) are sufficient to distinguish wood-knots and bark specimens from different forestry systems. For both forestry systems, branch and knot extractive contents are significantly lower than those of bark specimens are. These results are confirmed by the PCA which highlighted that the chemical composition of branch and knot woods is similar, but very different compared to that of bark samples.

LC-MS analyses revealed that main components of extracts in ethanol from $A F$ and FC branch wood were lignans, followed by sterols and flavonoids. Ethanol extracts from knots specimens are mainly composed by lignans followed by polyphenols, polysaccharides and flavonoids compounds. Finally, extracts in ethanol from bark specimens are rich in flavonoids components, followed by polyphenol and sterol. In addition, the chemical composition of ethanol extracts of bark samples depends on the bark position in the tree (branch, branch-trunk junction and trunk). The chemical compositions of ethanol extracts from branch and knot woods were slightly different between AF and FC samples, whereas the difference in chemical composition between AF bark and FC bark was more marked, specifically concerning the flavonoids compounds.

\section{Acknowledgements}

This work is part of the AGROBRANCHE (2018-2021) project ("Study of the valuation of branches in agroforestry for bio-based materials and green chemistry"), supported by the French Environment \& Energy Management Agency (ADEME). The authors gratefully acknowledge the GDR 3544 "Science du Bois" for its financial support of the STSM attributed to RD to carry out the LC-MS analyses at the LERMaB, University of Lorraine-Nancy (France).

\section{References}

Bhatia K, Rahman S, Ali M, Raisuddin S (2006). In vitro antioxidant activity of Juglans regia L. bark extract and its protective effect on cyclophosphamide-induced urotoxicity in mice. Redox Report 11 (6): 273-279. - doi: 10.1179/135100006 $\mathrm{X} 155030$

Donald A, Burns EW (2007). Handbook of nearinfrared analysis ( ${ }^{\text {rd }}$ edn). CRC Press, Boca Raton, FL, USA, pp. 834. [online] URL: http:// books.google.com/books?id=6EEd1aoukaoC Dupraz C, Burgess P, Gavaland A, Graves A, Herzog F, Incoll L, Jackson N, Keesman K, Lawson G, Lecomte I, Liagre F, Mantzanas K, Mayus M, Moreno G, Palma J, Papanastasis V, Paris P, Pilbeam D, Reisner $Y$, Vincent $G$, Van Der Werf W (2005). Synthesis of the silvoarable agroforestry for Europe project. INRA-UMR System Editions, Montpellier, France, pp. 254. [online] URL: http://www.researchgate.net/publication/ 230675921

Dupraz C, Liagre F (2019). Agroforesterie: des arbres et des cultures [Agroforestry: trees and crops] ( $2^{\text {nd }}$ edn). Edition France Agricole, Paris, France, pp. 432. [in French]

Fujimoto T, Kurata Y, Matsumoto K, Tsuchikawa S (2007a). Application of near infrared spectroscopy for estimating wood mechanical prop- 
erties of small clear and full length lumber specimens. Journal of Near Infrared Spectroscopy 16 (6): 529-537. - doi: 10.1255/jnirs.818

Fujimoto T, Yamamoto H, Tsuchikawa S (2007b). Estimation of wood stiffness and strength properties of hybrid larch by near-infrared spectroscopy. Applied Spectroscopy 61 (8): 882-888. - doi: 10.1366/000370207781540150 Halmemies ES, Brännström HE, Nurmi J, Läspä O, Alén R (2021). Effect of seasonal storage on single-stem bark extractives of Norway Spruce (Picea abies). Forests 12 (6): 736. - doi: 10.3390/ f12060736

Hapla F, Oliver-Villanueva JV, González-Molina JM (2000). Effect of silvicultural management on wood quality and timber utilisation of $\mathrm{Ce}$ drus atlantica in the European mediterranean area. European Journal of Wood and Wood Products 58 (1-2): 1-8. - doi: 10.1007/s001070050 377

Harmaen AS, Paridah MT, Jalaluddin H, Mohammad J, Khalid RH (2014). Influence of planting density on the fiber morphology and chemical composition of a new latex-timber clone tree of rubberwood (Hevea brasiliensis Muel. Arg.). BioResources 9 (2): 2593-2608. [online] URL: http://ojs.cnr.ncsu.edu/index.php/BioRes/article /view/5087

Haupt M, Leithoff H, Meier D, Puls J, Richter HG, Faix O (2003). Heartwood extractives and natural durability of plantation grown teakwood (Tectona grandis L.) - a case study. European Journal of Wood and Wood Products 61 (6): 473-474. - doi: 10.1007/s00107-003-0428-z

Jahanban-Esfahlan A, Ostadrahimi A, Tabibiazar M, Amarowicz R (2019). A comparative review on the extraction, antioxidant content and antioxidant potential of different parts of walnut (Juglans regia L.) fruit and tree. Molecules 24 (11): 2133. - doi: 10.3390/molecules24112133

Kebbi-Benkeder Z, Colin F, Dumarçay S, Gérardin $P$ (2015). Quantification and characterization of knotwood extractives of 12 European softwood and hardwood species. Annals of Forest Science 72: 277-284. - doi: 10.1007/s13595-014-04287

Kebbi-Benkeder Z, Dumarçay S, Touahri N, Manso R, Gérardin P, Colin F (2016). Les noeuds: un bois méconnu et une source importante de composés extractibles [Knots: an unknown wood and an important source of extractable compounds]. Revue Forestière Française 68 (1): 7-26. [in French] [online] URL: http://docum ents.irevues.inist.fr/handle/2042/61591

Kelley SS, Rials TG, Snell R, Groom LH, Sluiter A (2004). Use of near infrared spectroscopy to measure the chemical and mechanical properties of solid wood. Wood Science and Technology 38: 257-276. - doi: 10.1007/s00226-003-02135

Košíková B (2009). Morphological and chemical characteristics of stem and knot poplar wood. Wood Research 54 (3): 117-122. [online] URL: http://www.woodresearch.sk/wr/200903/13.pdf Leblon B, Adedipe O, Hans G, Haddadi A, Tsuchikawa S, Burger J, Stirling R, Pirouz Z, Groves K, Nader J, LaRocque A (2013). A review of near-infrared spectroscopy for monitoring moisture content and density of solid wood. The Forestry Chronicle 89 (5): 595-606. - doi: 10.5558/tfc2013-111

Malignier N, Balaguer F (2017). Current extent and trends of agroforestry in France. AGFORWARD Research Project, Annex to Deliverable 1.2. Association Française d'Agroforesterie, Auch, France, pp. 10. [online] URL: http://www. agforward.eu/documents/D1_2_Annex_Extent_ of_Agroforestry_France.pdf

Morikawa T, Ashitani T, Kofujita H, Takahashi K (2014). Antitermitic activity of extracts from Chamaecyparis obtusa branch heartwood. European Journal of Wood and Wood Products 72: 651-657. - doi: 10.1007/s00107-014-0830-8

Moulin JC, Arantes MDC, Vidaurre GB, Paes JB, Carneiro ACO (2015). Efeito do espaçamento, da idade e da irrigação nos componentes químicos da madeira de eucalipto [Effect of spacing, age and irrigation in chemical components of eucalyptus wood]. Revista Árvore 39 (1): 199-208. [in Portuguese] - doi: 10.1590/010067622015000100019

Naes T, Isaksson T, Fearn T, Davies T (2004). A user-friendly guide to multivariate calibration and classification. NIR Publications, Chichester, UK, pp. 344.

Nirmla Devi T, Apraj V, Bhagwat A, Mallya R, Sawant L, Pandita N (2011). Pharmacognostic and phytochemical Investigation of Juglans regia Linn. bark. Pharmacognosy Journal 3 (25): 39-43. - doi: 10.5530/pj.2011.25.7

Pace JHC, De Figueiredo Latorraca JV, Hein PRG, De Carvalho AM, Castro JP, Da Silva CES (2019). Wood species identification from Atlantic forest by near infrared spectroscopy. Forest Systems 28 (3): e015. - doi: 10.5424/fs/2019283-145 58

Pardon P, Mertens J, Reubens B, Reheul D, Coussement T, Elsen A, Nelissen V, Verheyen $\mathrm{K}$ (2020). Juglans regia (walnut) in temperate arable agroforestry systems: effects on soil characteristics, arthropod diversity and crop yield. Renewable Agriculture and Food Systems 35 (5): 533-549. - doi: 10.1017/S17421705190001 76

Ramalho FMG, Andrade JM, Hein PRG (2018). Rapid discrimination of wood species from native forest and plantations using near infrared spectroscopy. Forest Systems 27 (2): e008. doi: $10.5424 / f s / 2018272-12075$

Rowe JW, Conner AH (1979). Extractives in eastern hardwoods - A review. General Technical Report, Forest Products Laboratory, USDA Forest Service, Madison, WI, USA, pp. 67. [online] URL: http://www.fs.usda.gov/treesearch/pubs/ 9809

Rowell RM, Pettersens R, Han JS, Rowell JS, Tshabalala MA (2005). Cell wall chemistry. In: "Handbook of Wood Chemistry and Wood Composites" (Rowell RM ed). CRC Press, Boca Raton, FL, USA, pp. 35-72. [online] URL: http:// books.google.com/books?id=ekrLBQAAQBAJ

Salejda AM, Janiewicz U, Korzeniowska M, Kolniak-Ostek J, Krasnowska G (2016). Effect of walnut green husk addition on some quality properties of cooked sausages. LWT Food Science and Technology 65: 751-757. - doi: 10.1016/ j.Iwt.2015.08.069

Savitzky A, Golay MJE (1964). Smoothing and differentiation of data by simplified least squares procedures. Analytical Chemistry 36:
1627-1639. - doi: 10.1021/ac60214a047

Schwanninger M, Rodrigues JC, Fackler K (2011). A review of band assignments in near infrared spectra of wood and wood components. Journal of Near Infrared Spectroscopy 19 (5): 287308. - doi: 10.1255/jnirs.955

Schell J (1997). Interdependence of pH, malate concentration, and calcium and magnesium concentrations in the xylem sap of beech roots. Tree Physiology 17: 479-483. - doi: 10.1093/tree phys/17.7.479

Schimleck L, Evans R, llic J (2003). Application of near infrared spectroscopy to the extracted wood of a diverse range of species. IAWA Journal 24 (4): 429-438. - doi: 10.1163/22941932-900 00347

Taylor A, Gartner BL, Morrell JJ, Tsunoda K (2006). Effects of heartwood extractive fractions of Thuja plicata and Chamaecyparis nootkatensis on wood degradation by termites or fungi. Journal of Wood Science 52 (2): 147153. - doi: 10.1007/s10086-005-0743-6

Terrasse F, Brancheriau L, Marchal R, Boutahar N, Lotte S, Guibal D, Pignolet L, Candelier K (2021). Density, extractives and decay resistance variabilities within branch wood from four agroforestry hardwood species. iForest Biogeosciences and Forestry 14 (3): 212-220. doi: 10.3832/ifor3693-014

Toshiaki U (2001). Chemistry of extractives. In: "Wood and cellulosic chemistry" (De David NSH, Nobuo S eds). Marcel Dekker Inc., New York, USA, pp. 213-241.

Tsuchikawa S, Siesler HW (2003). Near-infrared spectroscopic monitoring of the diffusion process of deuterium-labeled molecules in wood. Part I: softwood. Applied Spectroscopy 57 (6): 667-674. - doi: 10.1366/0003702033220 05364

Vek V, Oven P, Ters T, Poljanšek I, Hinterstoisser $B$ (2014). Extractives of mechanically wounded wood and knots in beech. Holzforschung 68 (5): 529-539. - doi: 10.1515/hf-2013-0003

Workman JJ, Weyer L (2007). Practical guide to interpretive near infrared spectroscopy. CRC Press, Boca Raton, FL, USA, pp. 344.

Xu F, Zhong XC, Sun RC, Lu Q, Jones GL (2007). Chemical composition, fiber morphology, and pulping of P. bolleana Lauche. Wood and Fiber Science 38: 512-519.

Yi J, Sun Y, Zhu Z, Liu N, Lu J (2017). Near-infrared reflectance spectroscopy for the prediction of chemical composition in walnut kernel. International Journal of Food Properties 20 (7): 1633-1642. - doi: 10.1080/10942912.2016.1217006 Zakavi F, Golpasand Hagh L, Daraeighadikolaei A, Farajzadeh Sheikh A, Daraeighadikolaei A, Leilavi Shooshtari Z (2013). Antibacterial effect of Juglans regia bark against oral pathologic bacteria. International Journal of Dentistry 2013 (6): 1-5. - doi: 10.1155/2013/854765

\section{Supplementary Material}

Fig. S1 - Main chemical compounds found in ethanol extracts from bark wood (AF and FC), according to the sample position in walnut trees.

Link: Heim_3973@supploo1.pdf 